${ }^{1}$ ТОВ «ДТЕК Енерго», Київ, Україна

ОПРІСНЕННЯ ШАХТНИХ ВОД ПРИ ЗАКРИТТІ

ШАХТИ ім. М.І. СТАШКОВА ПрАТ «ДТЕК ПАВЛОГРАДВУГІЛЛЯ»

(C) I. Salieiev ${ }^{1}$

${ }^{1}$ LLC “DTEK Energy”, Kyiv, Ukraine

\title{
DESALINATION OF MINE WATER DURING THE CLOSURE OF THE MINE NAMED AFTER M.I. STASHKOVA OF PJSC "DTEK PAVLOHRADVUHILLIA"
}

Мета. Обгрунтувння доцільності опріснення шахтних вод для використання їх як питної води для населення при закритті вугільних шахт в Павлоградському регіоні та забезпечення виконання нормативних вимог, щодо збереження навколишнього серидовища, зокрема природних водоймів та грунтів.

Методика дослідження. Використано експериментально-аналітичний метод, що полягає у формуванні та аналізі світового досвіду опріснення води різного ступеня засоленості - від солоної морської, легко підсоленої до шахтної води. Також в роботі використаний метод хімічного аналізу води і вмісту в ній різних солей за допомогою випарювання.

Результати дослідження. Встановлено, що собівартість опріснення води технологією зворотного осмосу, порівняно з термальним методом дистиляції, зменшується за лінійним законом зі збільшенням продуктивності установок й обладнання і за потужності більш ніж 25 тис. т/добу не перевищує 1 дол. США. Окрім цього встановлено, що зі збільшенням складової розчинених речовин в шахтній воді, збільшуються також витрати на очищення самої води, вони збільшуються по експоненціальний залежності. Цей фактор залежить від збільшення таких речовин як магній, кальцій та натрій.

Наукова новизна. Вирішена актуальна, на даний час, задача економічної доцільності опріснення шахтної води на прикладі закриття шахт Західного Донбасу методом зворотного осмосу, який забезпечує питну воду для населення шахтарських міст і сприяє поліпшенню екологічної ситуації регіону за рахунок зменшення викидів у річки високомінералізованої шахтної води.

Практичне значення. Отримані результати та їх аналіз дозволяють констатувати, що при закритті вугільних шахт, які мають великий водоприплив і не високий ступінь мінералізації, доцільно використовувати опріснення шахтної води із залученням технології зворотного осмосу. Це дозволить поліпшити екологічну ситуацію у Павлоградському регіоні. Застосування отриманих результатів можна використовувати при проектуванні закриття шахт Західного Донбасу.

Ключові слова: закриття шахт, опріснення води, солі, зворотний осмос, питна вода.

Вступ. Згідно Екологічного прогнозу Організації економічного співробітництва та розвитку (ОЕСР), до 2050 року населення нашої планети зросте до 9,7 млрд осіб, а валовий світовий продукт (ВСП) за цей період часу збільшиться у 4 рази та складе 340000 млрд дол. США. У проведених дослідженнях ОЕСР відзначається, що світове споживання води до цього часу зросте на $55 \%$ за рахунок зростання промисловості (+400\% по відношенню до 2018 р.) [1]. 
Зіткнувшись з різким зростанням споживання, швидше за все людство відчує брак чистої питної води. Водний баланс річок порушиться, що піддасть значному ризику природних екосистем. Виснаження водоносних горизонтів може стати загрозою для припинення подачі питної води та води для сільскогосподарських потреб у різних регіонах світу.

Тому, на цьому тлі, пошук альтернативних і доступних джерел води став справжньою проблемою в усьому світі. Наявна велика кількість морської та солонуватої води на нашій планеті змушує задуматися фахівців щодо її опріснення (демінералізацію) та використанні в промисловості або побуті [2-5]. Технологія опріснення води набула широкого поширення у другій половині XX століття і за цей період часу внесла значний вклад у розвиток багатьох країн, які потребують альтернативних джерел води [6-9].

3 кожним роком опріснення стає все більш звичним і поширеним способом отримання якісної питної води. В даний час опріснення морської води широко використовується на Близькому Сході (OAE, Кувейт і Саудівська Аравія) в Іспанії, США, Канаді, Франції, Німеччині, Китаї, Австралії, Мексиці, Чилі та ряді інших країн [10-15]. Тільки в Канаді до 2030 року планують побудувати 20 нових станцій (заводів) з опріснення води [16].

Кількість опріснювальних станцій, що вводяться збільшується з року в рік по всьому світу. Тільки в 2008 році по всьому світу налічувалося близько 14000 промислових об'єктів з опріснення води, загальна потужність яких оцінювалася в 52,3 млн м³/доб [17]. До кінця 2017 року їх кількість збільшилася до 21000 і сумарна потужність до 122 млн м³/доб. За останніми оцінками, в період 2018 року в

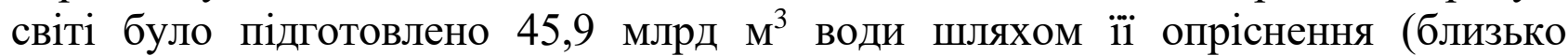
126 млн м³/доб) [18].

Методика та результати дослідження. Всього технології опріснення води застосовуються у 150 країнах світу. В даний час на ринку прісної води широке промислове застосування поки знайшли дві технології опріснення води - термальні (дистиляція) і мембранні (механічна). Деякі опріснювальні заводи використовують комбінації цих двох технологій $[8,15,19]$. Інші методи займають вкрай незначну нішу в загальному обсязі.

На рис. 1 представлені графіки сумарного об'єму потужностей мембранних і термальних опріснювальних станцій, які вводяться в світі. Як видно з представлених даних переважна перевага у всьому світі віддається мембранним технологіям опріснення води, що відображається експоненціальним їх зростанням. Використання мембранного опріснення різко збільшилось із початком 2000 року. Загальний обсяг продуктивності термічних опріснювальних станцій також збільшується щорічно, але тут тенденція має лінійну залежність.

У мембранній технології переважає метод опріснення води - зворотній осмос. На початок 2017 року в світі функціонує майже 12300 опріснювальних заводів із застосуванням цього методу. У загальному обсязі світового виробництва опріснення води метод зворотного осмосу займає $60 \%$. 


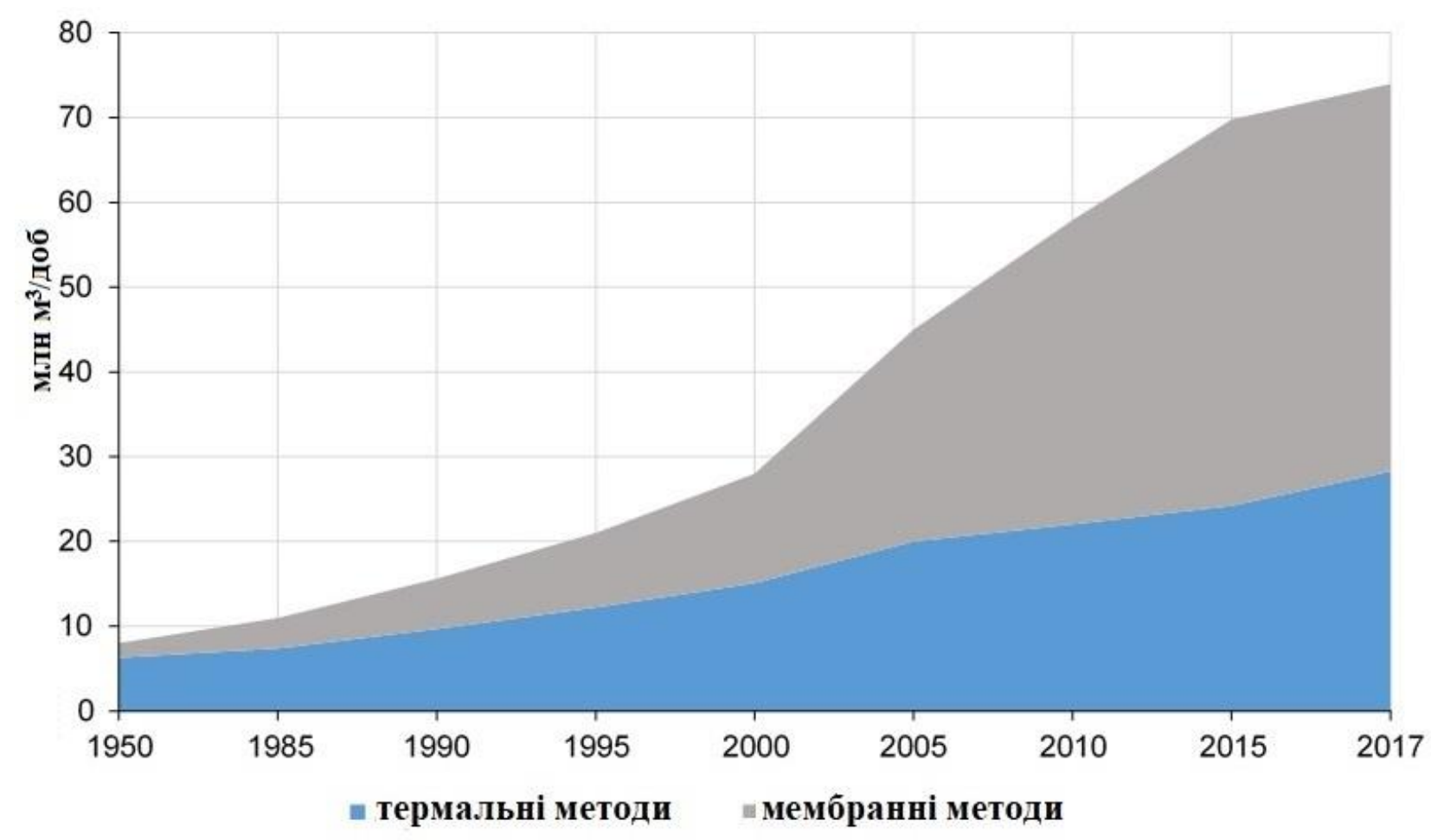

Рис. 1. Сумарна потужність опріснювальних заводів в світі з мембранним і термальним методами водопідготовки

Технології опріснення стрімко розвиваються по всьому світу, підвищується продуктивність та енергоефективність нових опріснювальних станцій, що вводяться в експлуатацію. За останні 20 років вартість опріснення $1 \mathrm{~m}^{3}$ води знизилася на 33\% і становить 0,13 \$ США [20, 21]. Тому промислове опріснення води для великих водоспоживачів стає більш вигідним в порівнянні з транспортуванням прісної води із віддалених джерел.

Динаміка зміни вартості опріснення $1 \mathrm{~m}^{3}$ на заводах, які були побудовані у період 1995 - 2015 гг. представлена на рис. 2.

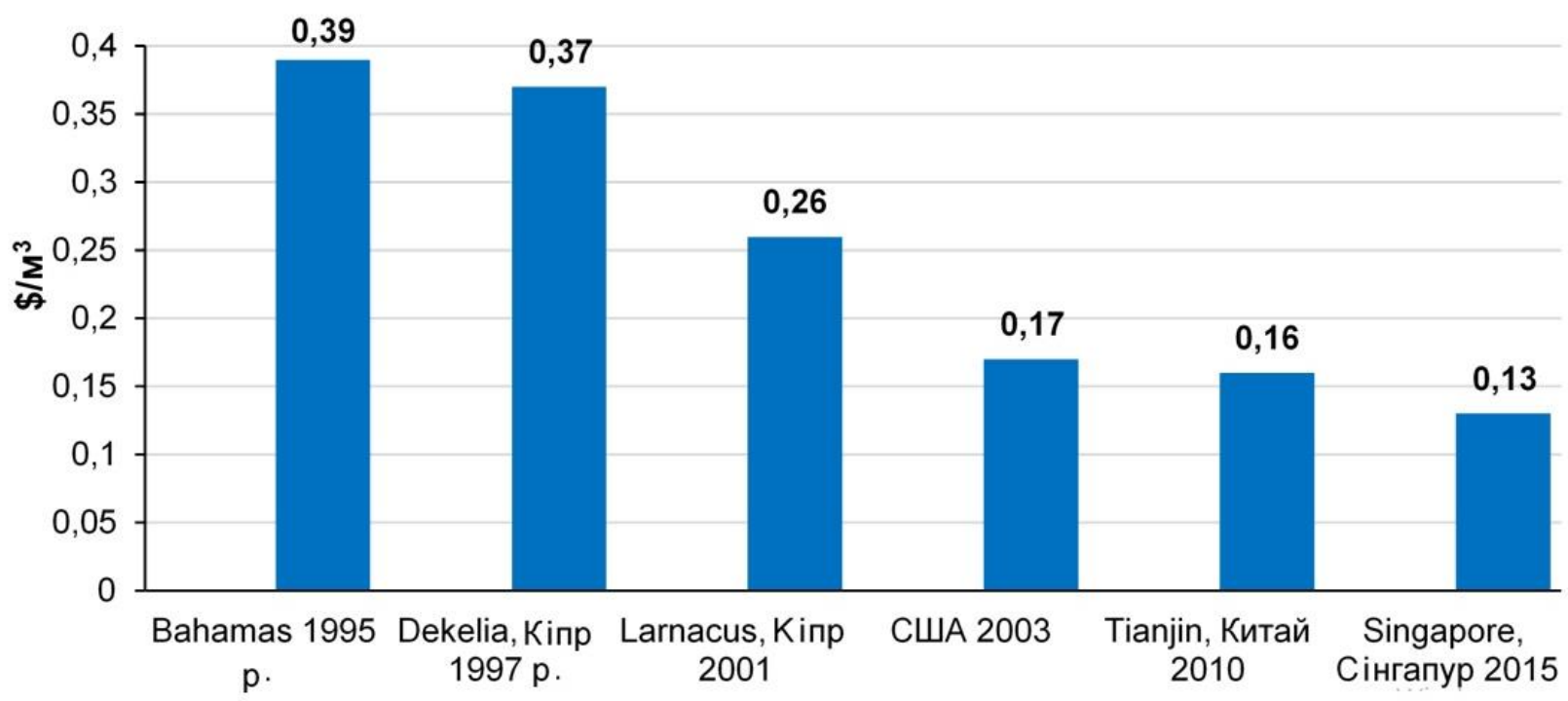

Рис. 2. Вартість опріснення $1 \mathrm{~m}^{3}$ на заводах, які були побудовані у період $1995-2015$ pp. 
Виконаний аналіз свідчить про те, що людство на Землі в найближчі роки буде відчувати великі проблеми з нестачею прісної питної води. Це в повній мірі стосується і шахтарських регіонів, де йде закриття шахт. Тому доцільно використовувати шахтні води після їх опріснення.

На шахті ім. М.І. Сташкова почався процес іiі ліквідації. На сьогоднішній день найбільш перспективним $є$ варіант повної фізичної ліквідації шахти, який передбачає природне затоплення всіх гірничих виробок протягом трьох років (за винятком стовбурів і вентиляційних свердловин) без погашення і вилучення кріплення. Даний варіант забезпечує мінімальні показники за економічним і часовим факторам, але при цьому створює певні ризики за гідрогеологічним фактором.

Поряд 3 цим гострою соціальною проблемою Павлогорадського району $є$ водопостачання його населених пунктів загальною чисельністю близько 300 тис. осіб. При цьому щоденний відбір підземних вод тільки однієї шахти Сташкова становить понад 30 тис. м³/доб. Ці води після опріснення можуть стати альтернативним джерелом водопостачання, здатним ліквідувати дефіцит водних ресурсів, що свідчить про необхідність створення підприємства для їх очищення та використання. Необхідно відзначити, що робота такого підприємства дозволить вирішити частково ще одну важливу соціальну проблему регіону, пов'язану зі скороченням робочих місць і зростанням вимушеного безробіття після передбачуваного в найближчі час закриття шахти.

Таким чином, у Западному Донбасі гостра нестача водних ресурсів і сформована екологічна і соціальна ситуація зумовлює необхідність створення нового підприємства по використанню шахтних вод для водопостачання населення шахтарських міст.

Тому на першому етапі необхідно виконати попередню техніко-економічну оцінку (ТЕО) доцільності опріснення води ш. М.І. Сташкова і її використання як питної для населення Павлоградського району.

Шахта ім. М.І. Сташкова розташована на території Павлогорадського і Петропавловского районів Дніпропетровської області. Найближчими великими насе-ленними пунктами $\epsilon$ м. Павлоград (розташований на відстані 30 км від підприємства), м Першотравенськ (20 км) та м Тернівка (15 км). Безпосередньо на шахтному полі розташовані села Дмитрівка, Миколаївка, Катеринівка, Петрівка і Мар'їна Роща. Географічне розташування шахти М.I. Сташкова i найближчих великих населених пунктів зображено на рис. 3.

Загальний водоприплив шахти ім. М.I. Сташкова змінюється в межах 1120 $1600 \mathrm{~m}^{3} /$ год і становить в середньому $1360 \mathrm{~m}^{3} /$ год. Щодоби з шахти відкачується 32640 м $^{3}$ води. 


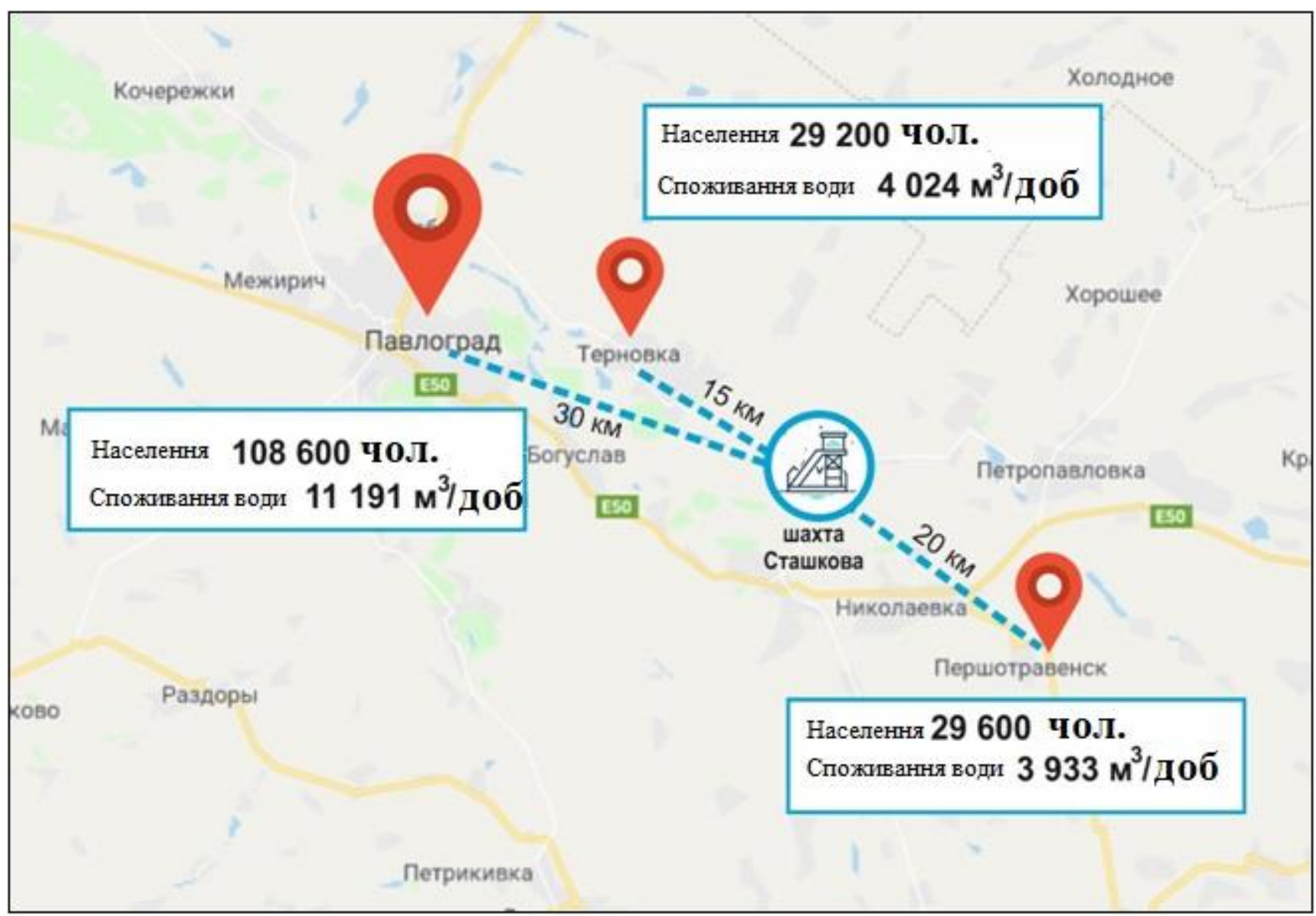

Рис. 3. Географічне розташування шахти ім. М.I. Сташкова і найближчих великих населених пунктів

Відкачування води забезпечується водовідливними установками. У шахті розташовано два водозбірники на горизонтах 225 і 300 м, ємністю відповідно 3000 i $1000 \mathrm{~m}^{3}$. Водозбірники обладнані насосами марки 8MC-7. Шахтна вода 3 водозбірнику горизонту 300 м перекачується у водозбірник горизонту 225 м, далі по трубопроводу видається на поверхню в водоотстойнікі.

Після відстоювання від зважених речовин і хлорування вода по трубопроводу перекачується в ставок, який розташований в балці Таранівка, куди скидають води шахт «Дніпровська» $\mathrm{i}$ «Самарська». Хімічний аналіз складу води шахти представлений у табл. 1.

Аналізуючи хімічний склад необхідно відзначити, що за типом переважають хлоридно-натрієві і хлоридно-натрієво-магнієві води 3 мінералізацією 2,9 - 4,0 г/дм³ , загальною жорсткістю - 28,55 ммоль/дм³ ${ }^{3}$ слаболужні 3 pH середовища 7,2. За технічними показниками - дуже жорсткі, вспінені, що при кип'ятінні відкладають велику кількість твердого котельного каменю. По відношенню до металевих конструкцій шахтні води сильно агресивні в залежності від сумарної концентрації сульфатів і хлоридів. Для питного і технічного водопостачання не придатні. 
Таблиця 1

Хімічний аналіз складу води шахти ім. М.І.Сташкова

\begin{tabular}{|c|c|c|c|}
\hline Показник & $\begin{array}{c}\text { Шахтна } \\
\text { вода для } \\
\text { відстійників }\end{array}$ & $\begin{array}{c}\text { Шахтна вода } \\
\text { після } \\
\text { відстійників }\end{array}$ & $\begin{array}{c}\text { Норми згідно } \\
\text { регламенту } \\
\text { скидання для } \\
\text { б. Свидовок }\end{array}$ \\
\hline БПК ${ }_{5}, \mathrm{мг} \mathrm{O}_{2} /$ дм $^{3}$ & - & 5,5 & 5,20 \\
\hline Водний показник, од. $\mathrm{pH}$ & 7,30 & 7,20 & $6,5-8,5$ \\
\hline Жорсткість, мг-екв/дм ${ }^{3}$ & 28,55 & 27,75 & - \\
\hline Зважені речовини, мг/дм³ & 100,6 & 44,8 & 22,50 \\
\hline Розчинений кисень, мг $\mathrm{O}_{2} /$ дм $^{3}$ & - & 6,9 & $>4,0$ \\
\hline Кольоровість, град & 10,72 & 10,13 & - \\
\hline Сухий залишок, мг/дм ${ }^{3}$ & 5762,00 & 5650,67 & 4565,00 \\
\hline Температура, C & 20,2 & 20,0 & - \\
\hline $\mathrm{XПК,} \mathrm{мГО/дм}{ }^{3}$ & - & 18,34 & 50,0 \\
\hline Алюміній, мг/дм ${ }^{3}$ & - & $<0,02$ & 0,019 \\
\hline Амоній & 0,32 & 0,31 & 0,40 \\
\hline Азот амонійний, мг/дм ${ }^{3}$ & 0,34 & 0,32 & 0,40 \\
\hline Аніони СПАВ, мг/дм ${ }^{3}$ & - & $<0,02$ & 0,20 \\
\hline Залізо общ. мг/дм ${ }^{3}$ & 0,62 & 0,60 & 0,16 \\
\hline Кальцій, мг/дм ${ }^{3}$ & 290,01 & 282,06 & - \\
\hline Кобальт, мг/дм ${ }^{3}$ & - & $<0,02$ & - \\
\hline Магній, мг/дм ${ }^{3}$ & 171,15 & 166,33 & - \\
\hline Марганець, мг/дм³ & - & 0,10 & 0,0068 \\
\hline Мідь, мг/дм ${ }^{3}$ & - & $<0,002$ & 0,0019 \\
\hline Нафтопродукти, мг/дм ${ }^{3}$ & 0,60 & 0,58 & 0,35 \\
\hline Нікель, мг/дм ${ }^{3}$ & - & $<0,005$ & - \\
\hline Нітрати, мг/дм ${ }^{3}$ & $<0,5$ & $<0,5$ & 1,49 \\
\hline Нітріти, мг/дм ${ }^{3}$ & 0,04 & 0,04 & 0,08 \\
\hline Сульфати, мг/дм ${ }^{3}$ & 406,15 & 398,33 & 1150,30 \\
\hline $\begin{array}{l}\text { Фосфати (ортофосфати), } \\
\text { мг/дм }\end{array}$ & 0,08 & 0,07 & 0,19 \\
\hline Хлор активний, мг/дм ${ }^{3}$ & - & - & - \\
\hline Хлориди, мг/дм ${ }^{3}$ & 3075,94 & 2950,46 & 1229,18 \\
\hline Хром, мг/дм ${ }^{3}$ & - & $<0,001$ & 0,00099 \\
\hline Цинк мг/дм ${ }^{3}$ & - & $<0,005$ & 0,005 \\
\hline
\end{tabular}


Встановлено, що такі токсичні компоненти, як кадмій, ртуть, берилій, молібден, телур, сурма, миш'як, вольфрам відсутні. Концентрація цинку, нікелю, хрому, фтору, ванадію та інших - нижче допустимих концентрацій.

Вартість $1 \mathrm{~m}^{3}$ води в Павлогорадському районі є однією 3 найвищих в Україні - 31,48 грн. Досягти зниження собівартості і підвищення якості води без масштабної реконструкції водоводу не представляється можливим.

Аналіз кількісних показників водоспоживання за основними містами Павлоградського району показує, що максимальна місячна потреба м. Павлограда становить $370970 \mathrm{~m}^{3}$, м. Тернівки - $154268 \mathrm{~m}^{3}$, та м. Першотравенська - 11838 м $^{3}$. Мінімальна місячна потреба по містах, що представлені, становить відповідно

$315819 \mathrm{~m}^{3} ; 112200 \mathrm{~m}^{3}$ і $89968 \mathrm{~m}^{3}$. Збільшення споживання води в зимовий період часу (січень - лютий) пов'язане з необхідністю подачі води на роботу міських котелень. Щодоби м. Павлоград споживає в середньому $11191 \mathrm{~m}^{3}$ води, м Тернівка - $4024 \mathrm{~m}^{3}$, м. Першотравенськ - $3933 \mathrm{~m}^{3}$.

Для виконання попередньої ТЕО нами прийнятий середньодобовий обсяг відкачуваних вод шахти ім. М.I. Сташкова $-\mathbf{3 0} 000 \mathbf{~ м}^{3}$.

Технологічна схема демінералізації і опріснення шахтних вод повинна забезпечувати якісні показники питної води, відповідні санітарним нормам і правилам «Гігієнічні вимоги до питної води, призначеної для споживання людиною» (ГСанПіН 2.2.4-171-10).

Тарифи на електроенергію, які діють в Дніпропетровській області для споживачів I класу напруження (понад 25 кВт) - 1,84 грн / кВт • год. Вартість обладнання, реагентів та витратних матеріалів конвертовані в національну валюту в розрахунку курсу 1 \$ США $=28,05$ грн.

Відомі такі технології опріснення: термальна, мембранна, хімічна і виморожування. Однак промислове застосування на практиці мають термальні і мембранні методи, які детально проаналізовані.

Термальний метод або дистиляція полягає в тому, що високомінералізовану морську воду нагрівають до кипіння і вихідну пару збирають і конденсують. Утворюється прісна вода - дистилят.

Зворотний осмос (Reverse Osmosis RO) - процес заснований на використанні напівпроникних мембран, за допомогою яких досягається розподіл розчину на розчинник і більш концентрований розчин. При опрісненні солоної води цим методом напівпроникна мембрана затримує солі і пропускає понад чисту воду у вигляді пермеата.

В процесі використовуються мікропористі гідрофобні мембрани, непроникні для перенесення рідкої води, в той час як водяна пара може проникати крізь них, маючи в якості рушійної сили різницю тиску пари між двома розчинами на границях розділу мембран, які виготовляються переважно з поліаміду або ацетату целюлози і випускаються у вигляді порожніх волокон або рулонів $[19,22]$. 
Рушійною силою зворотного осмосу є надлишок гідравлічного тиску над осмотичним тиском розчину, що піддається знесоленню. Осмотичний тиск розчинів навіть при невеликих концентраціях солей дуже велике. Тому для досягнення прийнятного ступеня опріснення солоної води зворотним осмосом застосовують високий робочий тиск $25-50 \mathrm{MПа} \mathrm{[23].}$

Зворотний осмос має низку істотних переваг в порівнянні з іншими методами опріснення води: відносно невисокі енерговитрати, установки конструктивно прості і компактні, їх робота може бути легко автоматизована. Тому, управління системою зворотного осмосу здійснюється в напівавтоматичному і автоматичному режимах.

Як свідчить практика, на економічну доцільність опріснення впливають багато параметрів, в першу чергу такі як: вартість електроенергії, хімічний склад вихідної води, технологія опріснення та ін. Виходячи з аналізу світового досвіду промислового опріснення [7, 24 - 26], складені усереднені статті витрат на підготовку води питної якості з морської води для різних технологій опріснення, які представлені у табл. 2

Необхідно відзначити, що шахтна вода в 6 разів має менше солей. Це істотно знизить витрати опріснення.

Таблиця 2

Усереднені витрати отримання питної води різними технологіями опріснення

\begin{tabular}{|c|c|c|c|c|c|c|}
\hline $\begin{array}{l}\text { Технологія } \\
\text { опріснення }\end{array}$ & 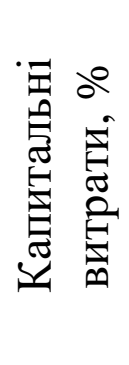 & 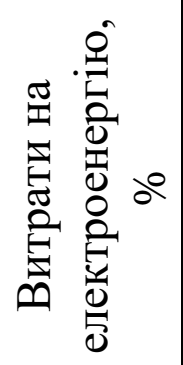 & 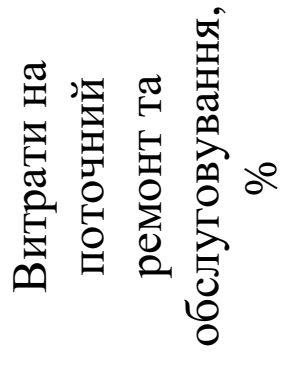 & 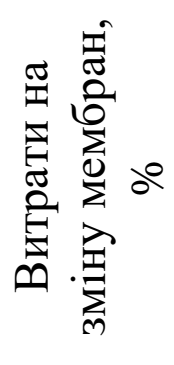 & 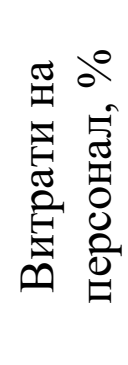 & 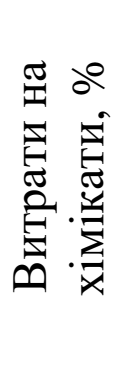 \\
\hline $\begin{array}{l}\text { Зворотний осмос } \\
\text { (мембранний) }\end{array}$ & 31 & 26 & 14 & 13 & 9 & 7 \\
\hline $\begin{array}{l}\text { Багатоступінчате } \\
\text { закипання } \\
\text { (термальне) }\end{array}$ & 42 & 41 & 8 & 0 & 7 & 2 \\
\hline
\end{tabular}

Загальні витрати можна розділити на капітальні та експлуатаційні. Капітальні витрати включають в себе оренду землі, будівництво споруд і будівель, купівлю обладнання, транспортні витрати та ін. До експлуатаційних слід віднести: технічне обслуговування і ремонт обладнання, заробітна плата персоналу, витрати на закупівлю хімічних реагентів та ін.

Виходячи із представлених даних, можна стверджувати, що в термальній технології багатоступінчатого закипання капітальні витрати і витрати на електроенергію вище ніж у зворотного осмосу, які сумарно займають $83 \%$ в загальній структурі витрат. 
Слід зауважити, що витрати на опріснення значно знижуються, коли замість морської води використовується солонувата вода (в першому наближенні ï можна розглядати як шахтну) і збільшується продуктивність опріснювальної станції. Зміна вартості отримання питної води в залежності від солонуватої вихідної води і продуктивності опріснювальної установки представлено у табл. 3.

Таблиця 3

Вартість виробництва питної води з морської та солонуватої води

\begin{tabular}{|c|c|c|}
\hline \multirow{2}{*}{$\begin{array}{c}\text { Продуктивність, } \\
\mathrm{M}^{3} / \text { сут }\end{array}$} & \multicolumn{2}{|c|}{ Вартість, \$ США $/ \mathrm{M}^{3}$} \\
\hline 3800 & морська вода & солонувата вода (шахтна) \\
\hline 7600 & 0,97 & 0,50 \\
\hline 19000 & 0,70 & 0,27 \\
\hline 38000 & 0,54 & 0,21 \\
\hline 57000 & 0,50 & 0,17 \\
\hline
\end{tabular}

3 аналізу представлених даних виходить, що кінцева вартість виробництва $1 \mathrm{~m}^{3}$ питної води з вихідної солонуватої всередньому на $35-40 \%$ нижче, ніж морської на опріснювальних станціях з однаковою продуктивністю.

Технологія зворотного осмосу характеризується більш низьким споживанням електроенергії в порівнянні з термальними технологіями опріснення. Тому собівартість отримання води питної якості, в більшості випадків нижче, ніж вартість води, отриманої за допомогою термальних технологій.

У всьому світі спостерігається зниження вартості опріснення для виробництва питної води. У найближчі роки очікується, що вартість опріснення води (особливо солонуватої) буде менше вартості будь-яких інших традиційних технологій водопідготовки. Через постійне вдосконалення технологій опріснення вартість отримання води питної якості буде щорічно знижуватися на $4-5 \%$.

Вартість опріснення $1 \mathrm{~m}^{3}$ води зворотним осмосом на заводах, які вводяться в експлуатацію в теперішній час нижче на $30-35 \%$ в порівнянні з тими, які будувалися 15 - 20 років тому. Такі зміни пояснюються не тільки швидким розвитком технології опріснення, а й зниженням витрат за рахунок збільшення потужності установок.

Проаналізувавши хімічний склад вихідних вод світових опріснювальних заводів, які використовують метод зворотного осмосу і порівнявши їх з водою шахти ім. М.I. Сташкова можна констатувати, що вода шахти має ступінь мінералізації в 6 разів нижче (табл. 4). Отже, і витрати на ії опріснення будуть нижче. Це дає підставу стверджувати, що собівартість отримання $1 \mathrm{~m}^{3}$ води питної якості шляхом очищення і знесолення шахтної води буде не дорожче 1 \$США.

Установки зворотного осмосу - це реальний прорив у проблемі отримання питної води шляхом опріснення. Установки масштабуються за модульним принципом. Можна спроектувати установку практично з будь-якою продуктивністю від кілька сотень літрів на добу для індивідуальних потреб до сотні тисяч літрів за добу для великих міст. 
Таблиця 4 Порівняння мінералізації вихідної води світових опріснювальних заводів і води шахти ім. М.I. Сташкова

\begin{tabular}{|c|c|c|c|c|c|}
\hline \multirow[b]{2}{*}{ Показник } & \multirow[b]{2}{*}{$\begin{array}{c}\text { Одиниця } \\
\text { миміру }\end{array}$} & \multicolumn{3}{|c|}{ Опріснювальний завод } & \multirow[b]{2}{*}{$\begin{array}{c}\text { Шахта } \\
\text { ім. } \\
\text { M.I. Сташкова }\end{array}$} \\
\hline & & $\begin{array}{c}\text { Fujairah } \\
\text { (OAЭ) }\end{array}$ & $\begin{array}{c}\text { Tampa } \\
\text { bay } \\
\text { (CША) }\end{array}$ & $\begin{array}{l}\text { Dagangxinquan } \\
\text { (Китай) }\end{array}$ & \\
\hline Кальцій & мГ/л & 450 & 400 & 412 & 290 \\
\hline Калій & мГ/л & 320 & 380 & 390 & 210 \\
\hline Магній & МГ/л & 1340 & 1262 & 1311 & 171 \\
\hline Сульфати & мГ/л & 3200 & 2650 & 2650 & 406 \\
\hline Хлориди & МГ/Л & 20180 & 18980 & 19500 & 3075 \\
\hline Фосфати & МГ/Л & 0,7 & 0,7 & 0,4 & 0,08 \\
\hline Залізо & МГ/Л & 0,5 & 0,4 & 0,3 & 0,62 \\
\hline $\begin{array}{l}\text { Сухий } \\
\text { залишок }\end{array}$ & мг/л & 36590 & 34483 & 32200 & 5762 \\
\hline
\end{tabular}

Висновки. Світова практика опріснення високомінералізованих вод щорічно збільшується і в теперішній час досягає 126 млн м³/доб. Лідируючими країнами за обсягами виробництва опріснення води є країни Близького Сходу (55\% от загальносвітового виробництва). По всьому світу налічується близько 21000 промислових об'єктів 3 опріснення морської і солонуватої води, при цьому кількість нових проектів, що вводяться в експуатацію продовжує зростати.

Встановлено, що до $60 \%$ опріснюваної води в світі виробляється із застосуванням технології зворотного осмосу. Сучасні промислові установки зворотного осмосу дозволяють опріснювати щодоби понад 500 тис. $\mathbf{m}^{3}$ води, при цьому щорічно збільшуються виробничі потужності технологічних ліній водопідготовки на 4,5\%, що говорить про високу ефективність і перспективність даного методу.

Вибір технології опріснення залежить від багатьох факторів, що впливають в першу чергу від якості вихідної мінералізованої води, необхідних обсягів водоспоживання, витрати електроенергії, що витрачається на роботу опріснювальної станції.

Рівень сучасного розвитку опріснювальної техніки дозволяє очистити до необхідних вимог будь-яку вихідну воду з низькою собівартістю, яка часто нижче традиційних методів очищення і перекачування води. У країнах світу, що розвиваються середня собівартість опріснення $1 \mathrm{~m}^{3}$ знаходиться в межах від 0,5 \$ США до 1,0 \$ США, а мінімальна становить 0,13 \$ США (Сінгапур).

Встановлено, що чим більше вміст солей у вихідній воді, тим вище необхідна ступінь очищення на виході, і тим більше витрати енергії. Наприклад, собівартість виробництва $1 \mathrm{~m}^{3}$ питної води з вихідної солонуватої в середньому на $35-40 \%$ нижче, ніж морський на опріснювальних станціях з однаковою продуктивністю. 
Таким чином, вивчивши світовий досвід опріснення можна стверджувати, що найбільш прийнятним методом опріснення води шахти ім. М.I. Сташкова $€$ зворотний осмос, який має найменші витрати в порівнянні з іншими методами $\mathrm{i}$ при цьому забезпечує високу ступінь чистоти води.

\section{Перелік посилань}

1. OECD. (2012). OECD Environmental Outlook to 2050: The Consequences of Inaction. Paris: OECD Publishing. https://doi.org/10.1787/9789264122246-en

2. Орлов, Н.С., \& Анисимов, С.И. (2017). Технико-экономическое обоснование разработки систем опреснения на основе традиционных и возобновляемых энергоресурсов. Современные наукоемкие технологии. Региональное приложение, 1, 95-112.

3. Bai, J., Zheng, S.H, \& Wu, Q.L. (2007). Study on the current status of water resources. Modern Agricultural Science and Technology, 12, 187-188.

4. Dai, J.Y., Wu, L.Y., Zhang, Y.G., \& Tang, Z.X. (2018). Brief analysis on environmental influence and comprehensive utilization of brine from thermal desalination. Guangdong Chemical, 45, 48-52.

5. Molden, D. (2007). Water for Food Water for Life: A Comprehensive Assessment of Water Management in Agriculture. Routledge.

6. Aish, A.M. (2011). Water quality evaluation of small scale desalination plants in the Gaza Strip, Palestine. Desalination and Water Treatment, 29(1-3), 164-173. https://doi.org/10.5004/dwt.2011.1765

7. Al Fraij, K.M., Al Adwani, A.A., \& Al Romh, M.K. (2004). The future of seawater desalination in Kuwait. In Desalination and Water Re-Use (pp. 83-84). Tudor Rose.

8. Encyclopedia of Desalination and Water Resources (EDWR). (2006). http://www.desware.net/desa4.aspx

9. Хорольський, А.О., Лапко, В.В., Саллі, В.С., \& Мамайкін, О.Р. (2020). Вибір технології демінералізації стічних вод, як складової технологічних потоків вугільних шахт. Збірник наукових прачь НГУ, 63, 61-73.

https://doi.org/10.33271/crpnmu/63.061

10. Jimenez-Cisneros, B. (2015). Responding to the challenges of water security: the Eighth Phase of the International Hydrological Programme, 2014-2021. Proceedings of the International Association of Hydrological Sciences, 366, 10-19. https://doi.org/10.5194/piahs-366-10-2015

11. Liu, T.-K., Sheu, H.-Y., \& Tseng, C.-N. (2013). Environmental impact assessment of seawater desalination plant under the framework of integrated coastal management. Desalination, 326, 1018. https://doi.org/10.1016/j.desal.2013.07.003

12. Micale, G., Cipollina, A., \& Rizzuti, L. (2009). Seawater Desalination for Freshwater Production. Seawater Desalination, 1-15. https://doi.org/10.1007/978-3-642-01150-4_1

13. World Bank. (2012). Renewable Energy Desalination: An Emerging Solution to Close the Water Gap in the Middle East and North Africa. Washington, DC: World Bank.

14. Rao, S.M., \& Mamatha, P. (2004). Water quality in sustainable water management. Current Science, 87(7), 942-947.

15. Shannon, M.A., Bohn, P.W., Elimelech, M., Georgiadis, J.G., Marinas, B.J., \& Mayes, A.M. (2008). Science and technology for water purification in the coming decades. Nature, 452, 301310. https://doi.org/10.1038/nature06599 
16. Lattemann, S., \& Höpner, T. (2008). Environmental impact and impact assessment of seawater desalination. Desalination, 220(1-3), 1-15.

https://doi.org/10.1016/j.desal.2007.03.009

17. Seamonds, A. (2008). Desalination in 2008: Global Market Snapshot. International Desalination Association (IDA): Topsfield, MA, USA. http://idadesal.org/wp-content/uploads/2008/10/2008ida-desalination-snapshot_october-2008.pdf

18. Eke, J., Yusuf, A., Giwa, A., \& Sodiq, A. (2020). The global status of desalination: An assessment of current desalination technologies, plants and capacity. Desalination, 495, 114633. https://doi.org/10.1016/j.desal.2020.114633

19. Bergman, R.A., \& Joseph, R.E. (2005). Post-Treatment of Reverse Osmosis and Nanofiltration Systems for Municipal Water Supply. In AWWA Membrane Technology Conference. Phoenix, Arizona, USA.

20. Installed Desalination Growth Slowed in 2011-2012. (2013). The International Desalination \& Water Reuse Quarterly Industry Website. Available online: http://www.desalination.biz/news/news_story.asp?id=6746\&title=Installed+desalination+growth+slowed+in+2011\%26\%238209\%3B2012

21. Ebensperger, U., \& Isley, P. (2005). Review of the Current State of Desalination. Working Paper 2005-2008. New York, USA: Environmental Policy Group at the Andrew Young School of Policy Studies, 34 p.

22. Khawaji, A.D., Kutubkhanah, I.K., \& Wie, J.-M. (2008). Advances in seawater desalination technologies. Desalination, 221(1-3), 47-69.

https://doi.org/10.1016/j.desal.2007.01.067

23. Дытнерский, Ю.И. (1978). Обратный осмос и ультрафильтращия. Химия.

24. Seigworth, A., Ludlum, R., \& Reahl, E. (1995). Case study: Integrating membrane processes with evaporation to achieve economical zero liquid discharge at the Doswell Combined Cycle Facility. Desalination, 102(1-3), 81-86. https://doi.org/10.1016/0011-9164(95)00044-3

25. Al-Karaghouli, A., \& Kazmerski, L.L. (2013). Energy consumption and water production cost of conventional and renewable-energy-powered desalination processes. Renewable and Sustainable Energy Reviews, 24, 343-356. https://doi.org/10.1016/j.rser.2012.12.064

26. Baawain, M., Choudri, B. S., Ahmed, M., \& Purnama, A. (2015). An Overview: Desalination, Environmental and Marine Outfall Systems. Recent Progress in Desalination, Environmental and Marine Outfall Systems, 3-10.

https://doi.org/10.1007/978-3-319-19123-2_1

\begin{abstract}
АННОТАЦИЯ
Цель. Обоснование целесеобразности опреснения шахтных вод для использования их как питьевой воды для населения при закритии угольных шахт в Павлоградском регионе и обеспечение исполнения нормативных требований к сбережению окружающей среды, в частности природных водоемов и грунтов.
\end{abstract}

Методика исследований. Использован экспериментально-аналитический метод, заключающийся в формировании и анализе мирового опыта опреснения воды различной степени засоленности - от соленой морской, легко подсоленной к шахтной воде. Также в работе ипользован метод химического анализа воды и содержания в ней разных солей при помощи выпаривания.

Результаты исследований. Установлено, что себестоимость опреснения воды технологией обратного осмоса, по сравнению с термальным методом дистилляции, уменьшается по линейному закону с увеличением производительности установок и оборудования и при мощности более 25 тыс. т/сут не превышает 1 долл. США. Кроме этого установлено, что с увеличением 
составляющей разбавленных веществ в шахтной воде, увеличиваются также и расходы на очищение самой воды, они увеличиваются по экспоненциальной зависимости. Этот фактор зависит от увеличения таких веществ как магний, кальций и натрий.

Научная новизна. Решена актуальная, на данный момент, задача экономической целесообразности опреснения шахтной воды при закрытии шахт методом обратного осмоса, который обеспечивает питьевой водой население шахтерских городов и способствует улучшению экологической ситуации за счет уменьшения выбросов в реки высокоминерализированной шахтной воды.

Практическое значение. Полученные результаты и их анализ позволяют констатировать, что при закрытии угольных шахт, имеющих большой водоприток и не высокую степень минерализации, целесообразно использовать опреснения шахтной воды с привлечением технологии обратного осмоса. Это позволит улучшить экологическую ситуацию в Павлоградском регионе. Применение полученных результатов можно использовать при проектировании закрытия шахт Западного Донбасса.

Ключевые слова: закрытие шахт, опреснения воды, соли, обратный осмос, питьевая вода.

\begin{abstract}
Purpose. Substantiating the expediency of mine water desalination for use as drinking water by the population after the coal mine closure in the Pavlohrad District and ensuring compliance with regulatory requirements for the preservation of the environment, in particular natural water bodies and soils.
\end{abstract}

Methods. An experimental-analytical method is used, which consists in the formation and analysis of global experience in water desalination at various degrees of salinity - from salty sea water, lightly salted to mine water.Also, the method of chemical water analysis and the content of various salts in it using evaporation is used in the work.

Findings. It has been determined that the cost of water desalination by reverse osmosis technology, in comparison with the thermal distillation method, decreases linearly with an increase in the productivity of plants and equipment and does not exceed $\$ 1$ in terms of a capacity of more than 25 thousand tons/day.In addition, it has been revealed that with an increase in the component of dissolved substances in mine water, the cost of purifying the water itself also increases.Itincreases by an exponential dependence.This factor depends on the increase in substances such as magnesium, calcium and sodium.

Originality. The urgent problem of the economic feasibility of mine water desalination by the reverse osmosis method has been solved using the example of closure of the Western Donbass mines.This method provides drinking water for the population of mining towns and contributes to the improvement of the ecological situation in the region by reducing emissions of highly mineralized mine water into the rivers.

Practical implications. The results obtained and their analysis make possible to state that when closing coal mines that have a large water inflow and a low degree of mineralization, it is advisable to use the method of mine water desalination by reverse osmosis technology. This will improve the ecological situation in the Pavlohrad District. The results obtained can be implemented when designing the Western Donbass mine closure.

Keywords: mine closure, water desalination, salt, reverse osmosis, drinking water. 